TITLE:

\title{
Mercury contamination and exposure assessment of fishery products in Korea(Abstract_要旨)
}

$\operatorname{AUTHOR}(S):$

Yang, Hye-Ran

\section{CITATION:}

Yang, Hye-Ran. Mercury contamination and exposure assessment of fishery products in Korea. 京都大学, 2016, 博士 (社会健康医学)

ISSUE DATE:

2016-03-23

URL:

https://doi.org/10.14989/doctor.k19637

RIGHT: 


\begin{tabular}{|c|c|c|c|}
\hline & 博士（社会健康医学） & & \\
\hline 論文題目 & \multicolumn{3}{|c|}{$\begin{array}{l}\text { Mercury contamination and exposure assessment of fishery products in } \\
\text { Korea } \\
\text { （韓国で販売されている魚製品の水銀含量と食慨曝露量評価 ） }\end{array}$} \\
\hline \multicolumn{4}{|c|}{ 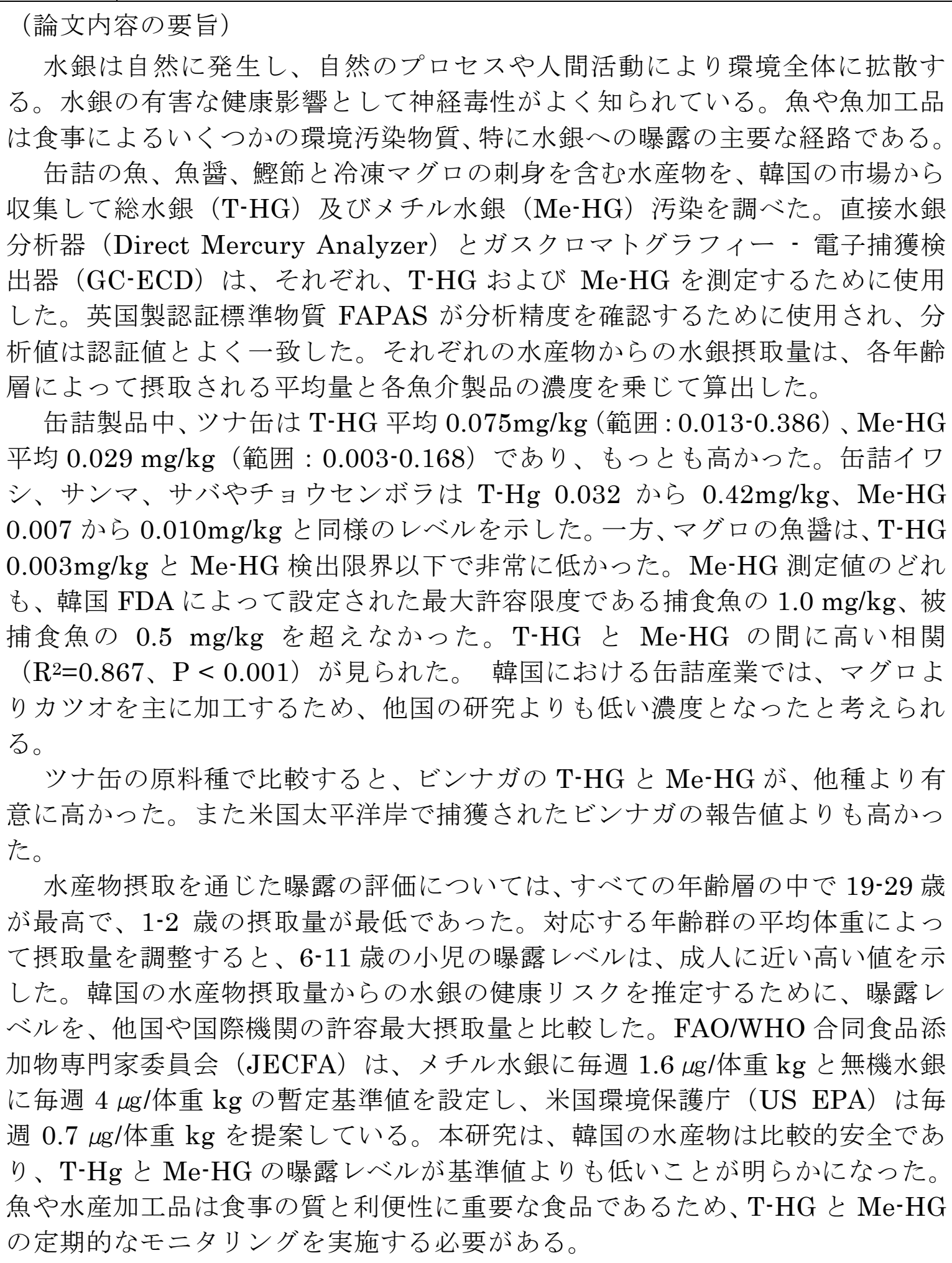 } \\
\hline
\end{tabular}

（論文審査の結果の要旨）

メチル水銀は神経毒性を示し、魚や魚加工品は食事によるメチル水銀曝露 の主要な経路である。缶詰の魚、冷凍・乾燥製品等の魚製品を、国際標準の 手続きに基づき、韓国 4 地域の市場から採取し、総水銀（T-HG）及びメチル 水銀 $(\mathrm{Me}-\mathrm{HG})$ の含有量を調べ、水産物からの摂取量を推定した。

缶詰製品中、ツナ缶は T-HG平均 $0.075 \mathrm{mg} / \mathrm{kg} 、 \mathrm{Me}-\mathrm{HG}$ 平均 $0.029 \mathrm{mg} / \mathrm{kg}$ と 最高值、他の缶詰製品でも T-Hg 0.032-0.42 mg/kg、 Me-HG $0.007-0.010 \mathrm{mg} / \mathrm{kg}$ とほぼ同レベルであった。全ての製品で、Me-HG值は韓国FDAの最大許容限 度を超えなかった。T-HGとMe-HGの間には高い相関（R²=0.867、P<0.001） が見られた。

水産物摂取を通じた推定曝露量は、全年齢層中19-29歳が最高で、1-2歳で 最低であった。年齢群の平均体重で補正した週当たりの曝露值 $(\mu \mathrm{g} / \mathrm{kg} / \mathrm{week})$ は、 T-Hg 0.078-0.150、 Me-Hg 0.024-0.049で、大きな年齢差はなかった。 水産物摂取量の国際基準であるJECFAによる暫定一週間当たりの耐容量 （ $\mu \mathrm{g} / \mathrm{kg} / \mathrm{week} ）(\mathrm{~T}-\mathrm{Hg} 4: \mathrm{Me}-\mathrm{Hg} 1.6$ ）に比べ、いずれも低值で健康へのリスク は極めて低いと判断された。

以上の研究は韓国における水産物による水銀摂取状況の解明に貢献し、そ のリスク管理に寄与するところが多い。

したがって、本論文は博士（社会健康医学）の学位論文として価値ある ものと認める。

なお、本学位授与申請者は、平成 27 年 12 月 24 日実施の論文内容とそ れに関連した試問を受け、合格と認められたものである。 